\title{
UPAYA MENINGKATKAN HASIL BELAJAR MATEMATIKA MELALUI PENGGUNAAN MEDIA MANIPULATIF
}

\author{
Oleh: Rita Rahmawati, M.Pd* dan Nurul Hijriah**
}

\begin{abstract}
ABSTRAK
Tujuan yang ingin dicapai dalam penelitian ini adalah (1) untuk mendeskripsikan aktivitas belajar peserta didik dalam pembelajaran matematika dengan menggunakan media manipulatif, (2) untuk mendeskripsikan peningkatan hasil belajar matematika dengan menggunakan media manipulatif. Jenis penelitian ini adalah penelitian tindakan kelas (PTK). Subjek dalam penelitian ini adalah peserta didik kelas IV SDN 2 Kereng Bangkirai. Teknik pengumpulan data dalam penelitian ini yaitu tes, observasi, dan teknik analisis data dalam penelitian ini adalah kuantitatif-kualitatif. Hasil penelitian menunjukan bahwa (1) ada peningkatan aktivitas belajar peserta didik, dan (2) ada peningkatan hasil belajar matematika dengan menggunakan media manipulatif pada peserta didik kelas IV SDN 2 Kereng Bangkirai Tahun Pelajaran 2014/2015 dengan nilai ketuntasan klasikal yaitu $100 \%$.
\end{abstract}

Kata Kunci: hasil belajar matematika, media manipulatif

\section{PENDAHULUAN}

Berdasarkan hasil observasi yang dilakukan peneliti pada kelas VI di SDN-2 Kereng Bangkirai maka peneliti menemukan masalah atau kendala yaitu kurangnya pemahaman peserta didik terhadap materi pembelajaran Matematika, hal ini disebabkan pembelajaran yang kurang inovatif serta tidak menggunakan media pembelajaran, sehingga mengakibatkan peserta didik sering menunjukkan sikap belajar yang kurang baik. Misalnya, kurang aktifnya peserta didik dalam proses pembelajaran, peserta didik merasa bosan, jenuh dan tidak bersemangat, akibatnya kurangnya pemahaman peserta didik pada materi pembelajaran.
Djamarah (2011:13) belajar adalah serangkaian kegiatan jiwa raga untuk memperoleh sesuatu perubahan tingkah laku sebagai hasil dari pengalaman individu dalam interaksi dengan lingkungannya yang menyangkut kognitif, afektif, dan psikomotorik

Salah satu penyebab terjadinya hal tersebut adalah karena pendidik kurang tepat dalam memilih media pembelajaran yang sesuai dengan materi yang disampaikan sehingga hasil belajar tidak memuaskan.

Sudjana (2006;3) menyatakan bahwa "Hasil belajar peserta didik pada hakikatnya adalah perubahan tingkah laku dan kemampuankemampuan yang dimiliki peserta didik setelah ia menerima pengalaman belajarnya. Hasil belajar 
peserta didik dalam mata pelajaran Matematika masih rendah yaitu dengan rata-rata 58,75. Sedangkan standar KKM yang ditetapkan oleh SDN-2 Kereng Bangkirai yaitu ketuntasan kelas dengan rata-rata 60 . Ada 11 peserta didik (60\%) dari jumlah peserta didik di kelas IV mendapat nilai $<60$ dan sisanya 9 peserta didik (40\%) mendapat nilai $\geq$ 60. Hal tersebut berdasarkan informasi yang diperoleh peneliti dari wali kelas IV SDN-2 Kereng Bangkirai.

Peneliti menggunakan media manipulatif dalam pembelajaran matematika SD guna membuat peserta didik lebih mudah memahami materi pembelajaran dan bisa membuat peserta didik menjadi lebih aktif berpartisipasi dalam belajar. Muhsetyo dkk (2007:20) media manipulatif merupakan segala benda yang dapat dilihat, disentuh, didengar, dirasakan, dan dimanipulasikan.

Benda manipulatif dapat diartikan sebagai alat untuk menerangkan atau mewujudkan konsep matematika, alat yang digunakan dapat berupa benda nyata. Hal ini menunjukkan bahwa segala sesuatu yang bisa dan biasa ditemukan peserta didik dalam kesehariannya.

Oleh sebab itu peneliti ingin mencoba menggunakan media alat peraga manipulatif untuk meningkatkan kemampuan peserta didik pada mata pelajaran
Matematika agar mencapai standar kriteria ketuntasan minimal (KKM) yang ditetapkan oleh SDN-2 Kereng Bangkirai. Berdasarkan uraian masalah diatas maka peneliti tertarik untuk melakukan penelitian tindakan kelas yang berjudul "Upaya Meningkatkan Hasil Belajar Matematika Melalui Penggunaan Media Manipulatif.

Penelitian akan dilakukan di kelas IV SDN-2 Kereng Bangkirai Tahun Pelajaran 2014/2015. Adapun tujuan yang ingin dicapai dalam penelitian ini adalah: Untuk mengetahui aktivitas belajar peserta didik dalam pembelajaran Matematika dengan menggunakan media manipulatif pada peserta didik Kelas IV SDN-2 Kereng Bangkirai dan Untuk mengetahui ada tidaknya peningkatan hasil belajar Matematika dengan menggunakan media manipulatif pada pelajaran peserta didik Kelas IV SDN-2 Kereng Bangkirai.

\section{METODE PENELITIAN}

Penelitian ini dilaksanakan dengan menggunakan metode Penelitian Tindakan Kelas (Classroom action research). Menurut Kunandar (2011:42) penelitian tindakan kelas merupakan bagian dari penelitian tindakan (action research), dan penelitian tindakan ini bagian dari penelitian pada umumnya. Adapun subjek dalam penelitian ini adalah peserta 
didik kelas IV SDN-2 Kereng Bangkirai yang berjumlah 20 orang. Teknik pengumpulan data mengunakan observasi dan tes, sedangkan untuk teknik analisis data dilakukan secara kualitatif dan kuantitatif yang kemudian di deskripsikan.

\section{HASIL DAN PEMBAHASAN}

Meningkatnya aktivitas peserta didik terlihat dari skor nilai siklus I dengan rata-rata 2.92 dan skor nilai siklus II dengan rata-rata 4 dikategorikan baik sekali. Pretest dilaksanakan dikelas IV SDN-2 Kereng Bangkirai Palangkaraya pada hari kamis tanggal 21 mei 2015, dengan jumlah peserta didik yang terlibat dalam aktivitas penelitian sebanyak 20 orang.

Hasil perolehan nilai pada pretest ini belum maksimal, karena belum ada peserta didik yang memperoleh nilai ketuntasan baik secara individual maupun secara klasikal dengan nilai rata-rata 33,5. Berdasarkan perolehan tersebut maka perlu dilakukan tahapan selanjutnya yakni melakukan siklus I dengan beracuan pada hasil pretest yang telah diperoleh.

Pada siklus ini peneliti mulai melakukan rencana pembelajaran dengan menggunakan media manipulatif, ternyata pada tahap evaluasi hasil belajar peserta didik mengalami peningkatan dengan 12 peserta didik yang sudah mencapai KKM dengan nilai rata-rata 54 dan terdapat 8 orang peserta didik yang belum tuntas. Berdasarkan perolehan tersebut ketuntasan belajar peserta didik masih belum dikatakan tuntas karena belum 100\%, maka peneliti melakukan siklus II berdasarkan refleksi pada siklus I.

Siklus II dilaksanakan di kelas

IV SDN-2 Kereng Bangkirai Palangkaraya pada hari senin tanggal 25 mei 2015, dengan jumlah peserta didik yang terlibat dalam aktivitas penelitian sebanyak 20 orang. Hasil belajar peserta didik pada siklus ini menunjukkan tingkat ketuntasaan klasikal yang maksimal (100\%), yang semula pada pretest dan siklus I ada peserta didik yang belum tuntas ternyata pada siklus II hasil belajar peserta didik 100\% tuntas.

Peserta didik yang belum
tuntas hasil belajarnya
merekaa kurang aktif
pembelajaran dan kurang bertanya pada guru apabila ada yang belum dimengerti, mereka juga kurang aktif dalam memperhatikan penjelasan yang disampaikan guru. Pada siklus II ketuntasan hasil belajar peserta didik sudah mencapai $(100 \%)$ tuntas atau sudah mencapai KKM yang telah ditetapkan sekolah yaitu 60 .

Hal ini menunjukkan bahwa pembelajaran sudah dapat dikatakan berhasil dan melebihi nilai ketuntasan klasikal yaitu 87,5 \%. Jadi, tidak perlu diadakan tindak lajut lagi ke siklus berikutnya. 


\section{KESIMPULAN}

Berdasarkan hasil penelitian maka dapat disimpulkan bahwa:

1. Terjadi peningkatan aktivitas peserta didik dalam pembelajaran matematika dengan menggunakan media manipulatif di kelas IV SDN-2 Kereng Bangkirai dengan adanya keterlibatan peserta didik dalam proses pembelajaran dari tahap awal sampai siklus II.

2. Ada peningkatan hasil belajar matematika peserta didik setelah diajarkan menggunakan media manipulatif di kelas IV SDN-2 Kereng Bangkirai Tahun Pelajaran 2014/2015.

\section{DAFTAR PUSTAKA}

Kunandar, 2007, Guru Profesional, Jakarta: PT. Raja Grafindo Persada.

Sudjana. 2006. Penilaian Hasil Proses Belajar Mengajar, Bandung: PT. Remaja Rosdakarya.

Djamarah, S, 2011, Psikologi Belajar, Jakarta: PT. Rineka Cipta.

Muhsetyo, dkk, 2007, Pembelajaran Matematika SD, Jakarta : Universitas Terbuka. 